\title{
Gradhiva
}

GRADHI

Revue d'anthropologie et d'histoire des arts

$8 \mid 2008$

Mémoire de l'esclavage au Bénin

\section{Commémoration de la Traite Atlantique à Ouidah}

Commemoration of the Atlantic Slave Trade in Ouidah ${ }^{1}$

Robin Law

\section{(2) OpenEdition}

Journals

Electronic version

URL: http://journals.openedition.org/gradhiva/1162

DOI: $10.4000 /$ gradhiva. 1162

ISSN: 1760-849X

\section{Publisher}

Musée du quai Branly Jacques Chirac

\section{Printed version}

Date of publication: 15 November 2008

Number of pages: $10-27$

ISBN: 978-2-915133-94-3

ISSN: 0764-8928

\section{Electronic reference}

Robin Law, "Commémoration de la Traite Atlantique à Ouidah », Gradhiva [Online], 8 | 2008, Online since 15 November 2011, connection on 10 December 2020. URL : http://journals.openedition.org/ gradhiva/1162 ; DOI : https://doi.org/10.4000/gradhiva.1162 


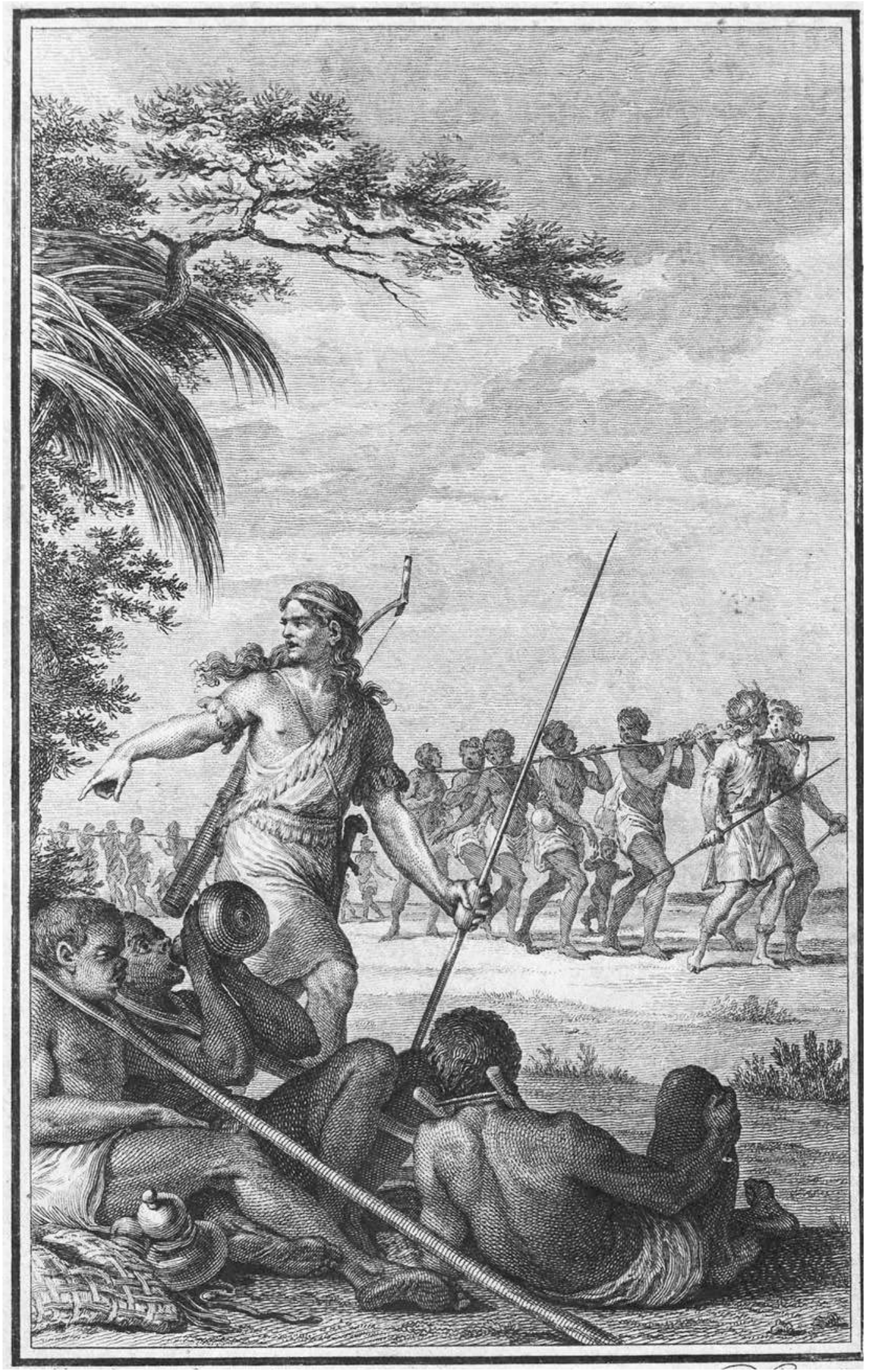

Fig. 1 Nicolas Delaunay, Esclaves conduits par les marchands,

d'après Jean-Michel Moreau le Jeune, vers 1780, musée du quai Branly @ RMN, DR. 


\section{DOSSIER || Robin Law}

\section{Commemoration of the Atlantic Slave Trade in Ouidah ${ }^{1}$}

$\mathrm{T}$ he recent development of projects of historical commemoration of the Atlantic slave trade in various countries in Africa has not been without controversy, with strong disagreements provoked in particular by the Maison des Esclaves on Gorée Island in Senegal and the historical exhibition at Cape Coast Castle in Ghana. In the case of Goree, the controversy was essentially about the authenticity of the Maison des Esclaves as a monument of the slave trade, with critics arguing that there was no solid evidence that any large number of slaves had in fact been exported through the building (or indeed, through Gorée more generally). ${ }^{2}$ In that of Cape Coast Castle, the controversy related to the ownership rather than to the authenticity of historical commemoration. The Cape Coast exhibition had been projected initially as one on the history of the Central Region of Ghana, in which the Atlantic slave trade would be a prominent but not all-engrossing theme; but it was in effect hijacked for a different agenda, that of the small community of African-Americans from the USA resident in Ghana, which privileged not only the slave trade relative to other aspects of Ghanaian history, but also the history of the African diaspora which the slave trade created relative to that of Africa itself (Kreamer 1997; Osei-Tutu 2002). The tensions between African-Americans and Ghanaians on this issue also reflected a feeling on the part of the former that the latter were reluctant to admit the role of indigenous African agency (or "complicity") in the operation of the slave trade.
In contrast, one aspect of the Cape Coast exhibition which appears to have provoked much less (if any) conscious reflection or controversy, is that the African diaspora in the Americas was represented in it primarily by the case of the USA, despite the fact that the USA accounted for only a very small proportion of the transAtlantic slave trade; many more of the slaves exported through Cape Coast would have gone to the Caribbean, especially Barbados and Jamaica, than to continental North America. The exhibition thus involved the marginalization not only of Africa relative to its diaspora in the Americas, but also of other parts of the Diaspora relative to the USA. A feature common to both the Goree and Cape Coast projects, which likewise seems not to have been perceived as controversial, was their presentation of the experience of the enslaved in terms which stressed their separation from their African roots. The Maison des Esclaves of Gorée provides what is surely the most powerful visual image of the slave trade, in its back door giving onto the beach, through which slaves were presumably taken to be embarked for shipment to the Americas, dubbed La Porte du Non-Retour. This concept has now been imitated at Cape Coast Castle, with the designation there also of the gateway facing

1. Earlier versions of this paper were read at seminars of the Centre of Commonwealth Studies of the University of Stirling, Sept. 1998 and the Harriet Tubman Resource Center on the African Diaspora, York University, Toronto, Feb. 1999.

2. The controversy was the subject of a conference at Gorée in April 1997 (Samb 1997). 
the beach as the "Door of No Return". The implication is that the transported enslaved Africans -and also their descendants, at least until the recent development of African-American tourism to these sites of memorywere effectively cut off from contact with the African homeland. Here again, however, while this emphasis on deracination may be thought to fit the historical experience of African-Americans in the USA, it is less evident that it is appropriate for other sections of the African diaspora, such as those in Brazil, Cuba or Haiti, where local religious traditions (candomblé in Brazil, santería in Cuba, and vaudou in Haïti) exhibit strong influences from Africa, which moreover can be related to specific differentiated African homelands. There was also a significant re-emigration to Africa of former slaves of African birth or descent from Brazil already during the period of the Atlantic slave trade, in the eighteenth and nineteenth centuries.

The present paper seeks to illustrate the possibility of alternative modes of representation of the slave trade, and more especially of its significance for Africa, through a study of the case of the Republic of Bénin (formerly Dahomey), and more particularly of the Musée d'Histoire and other commemorative projects located in the coastal town (and former slave-trading "port") of Ouidah. ${ }^{3}$ At Ouidah, there seems to be less disposition to deny the community's historical involvement in the slave trade, and much more interest in the reciprocal linkages which that trade created between Africa and its diaspora in the Americas.

\section{Ouidah and the Slave Trade}

In contrast to the controversial case of the Maison des Esclaves at Goree, the importance of Ouidah in the Atlantic slave trade is not in question; it was a major centre of the slave trade for almost two hundred years (Law 2004). Strictly speaking, it was not a "port", although conventionally described as such, since it is located inland, actually about $3.5 \mathrm{~km}$ from the sea. The slaves sold through Ouidah had therefore to be marched overland south from the town to be embarked from the seashore-along the path nowadays referred to as La Route de l'Esclave. Originally the town belonged to the kingdom of Hweda (whence the name "Ouidah"), ${ }^{4}$ whose capital was at Savi about $10 \mathrm{~km}$ further inland, but in 1727 the Hweda kingdom was conquered by the inland power of Dahomey, and from then until the French colonial occupation in 1892, Ouidah remained subject to Dahomey and served as its principal outlet for the Atlantic trade.
Although local tradition maintains that the first European traders in Ouidah were the Portuguese -presumably in the sixteenth or early seventeenth century, the effective opening Ouidah as a slave "port" dates from 1671, when the French West Indies Company established a factory there, which was upgraded into a fort in 1704. The English Royal African Company also established a factory (likewise, later fortified) in Ouidah in the 1680s, and a Portuguese fort was added in 1721. All three forts were maintained through the eighteenth century, but were abandoned when the slave trade became illegal in the early nineteenth century. Significant exports of slaves from Ouidah continued, however, even after the legal abolition of the trade, down to the early 1860 s. Over the entire period from the $1670 \mathrm{~s}$ to the 1860 s, according to the most recent estimate, Ouidah exported over a million slaves, making it one of the leading slaving "ports" in sub-Saharan Africa -in fact, probably second in importance only to Luanda, in Angola. ${ }^{5}$ The linkages of Ouidah in the slave trade were mainly to Brazil, especially to the province of Bahia. Brazil is thought to have taken around $60 \%$ of all slave exports from the Ouidah region, with the French Caribbean (especially Saint-Domingue, modern Haïti) in the eighteenth century and Spanish Cuba in the illegal trade of the nineteenth century also major destinations; whereas by contrast, relatively few slaves from Ouidah went to the British Caribbean or North America.

The commercial importance of Ouidah began to decline in the second half of the nineteenth century, relative to the new port of Cotonou to the East -probably because the latter was better situated in relation to navigable inland waterways, an advantage which became critical with the shift from the slave trade to exports of bulk agricultural produce (especially palm oil). The decline was accelerated by the construction of modern port facilities at Cotonou, beginning with the building of a wharf in 1893, and the export trade through Ouidah had ceased completely by the 1940 . The town nowadays is altogether commercially marginalized. Despite this economic decline, however, Ouidah remained an important centre of western culture and

3. My profound thanks to Martine de Souza for her assistance on several visits to Ouidah. On slave trade commemoration in Ouidah, see also Sutherland 1999; Cafuri 2000; Rush 2001; and, for observations on Ouidah in a comparative perspective, Singleton 1999.

4. The correct indigenous name of the town, still used by its inhabitants when speaking in the local language (Fon) rather than in French, is Glehwe.

5. Statistical data extracted from Eltis and Richardson 1997; Eltis, Lovejoy and Richardson 1999. 


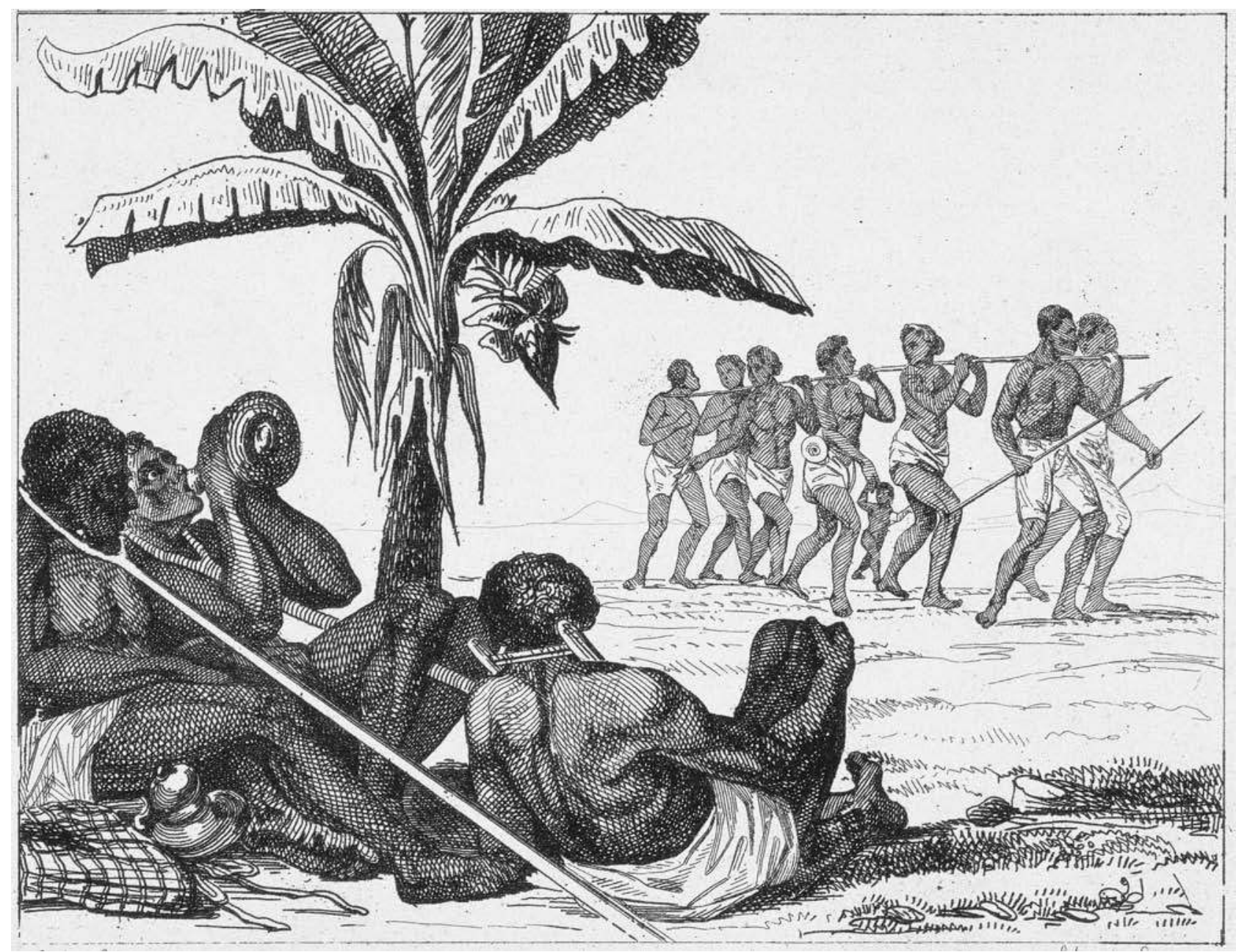

Fig. 2 Eugène Ferdinand Buttura (dessinateur), Mr Lalement (graveur), Nègres de traite en voyage, d'après Jean-Michel Moreau le Jeune, début du xIxe siècle, musée du quai Branly @ RMN, photo Jean-Gilles Berizzi.

education under French colonial rule, as the site of a Roman Catholic seminary opened in 1914, and Ouidah families remain disproportionately prominent within the educated elite of modern Bénin.

\section{Memory of the Slave Trade in Ouidah}

Ouidah is a community with a strong sense of its history, in which consciousness of present decline is compensated for by an awareness of the town's former importance. This has been reflected, most obviously, in the publication of several books and pamphlets on local history, the most substantial study being a history of the town by Casimir Agbo (Agbo 1959). There is nowadays even a local history society, associated with the Musée d'Histoire de Ouidah - the Association des Amis du Musée, formed in 1987.
The community's participation in the Atlantic slave trade is an openly acknowledged aspect of that history. In contrast to what has been suggested for Ghana, in Ouidah the role of African agency in the operation of the trade is explicitly avowed. ${ }^{6}$ Continuity from the era of the slave trade to the present is acknowledged, not only at the abstract level of the community as a whole, but in relation to many particular families resident in the town. The leading families of contemporary Ouidah are, for the most part, descended from ancestors who were prominent slave-traders in the late eighteenth and early nineteenth centuries. The best-known example is the de Souza family, descended from the Brazilian

6. The contrast between Ghana and Bénin in this respect is also noted by Singleton 1999. This view contrasts with the perception of Sutherland 1999: 196, of "a systematic avoidance of the question of African guilt", but his analysis is narrowly focused on one particular festival. 


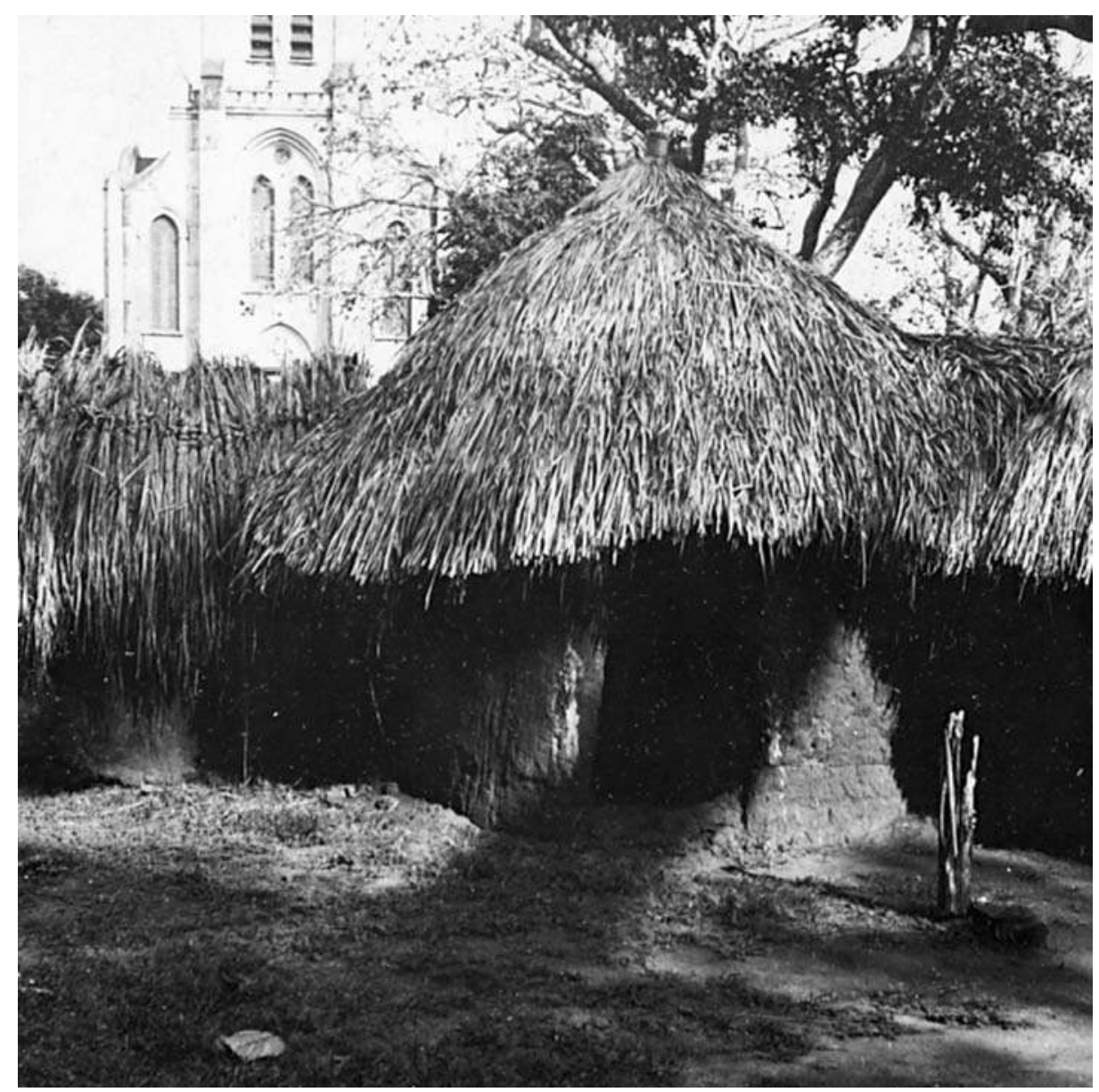

Fig. 3 Marcel Griaule, temple des serpents, Ouidah, 1931 @ musée du quai Branly. La case, devenue "temple ", fait toujours face à la cathédrale de Ouidah visible en arrière-plan.

Fig. 4 Bernard Maupoil, Enfant d'Ouidah avec des pythons royaux, 1934-1936 @ musée du quai Branly. Le Python correspond à l'entité vodun Dan, prééminent à Ouidah.

Fig. 5 Temple des pythons, Ouidah. Photo G. Ciarcia (page ci-contre).

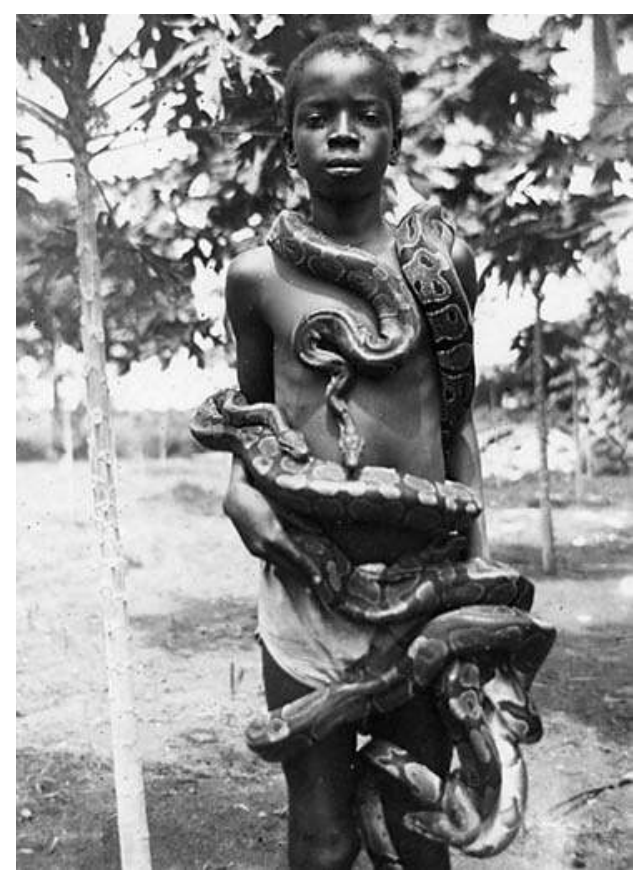

slave-trader Francisco Felix de Souza (died 1849), who settled in Ouidah in the early nineteenth century, eventually becoming the commercial agent to King Guezo of Dahomey, in which capacity he dominated the slave trade from the town from the 1820 s to the early 1840 s. $^{7}$ But there are also purely indigenous families who are likewise descended from slave-traders. The five leading Dahomian merchant families in the nineteenth century-Adjovi, Codjia, Gnahoui, Hodonou, Houenou (Quénum)- all of which remain prominent in the town today, are known to have been founded by persons who began their careers as slavers, though they moved into other forms of trade (especially in palm oil) in the second half of the nineteenth century. ${ }^{8}$

7. For traditions of the de Souza family, see de Souza 1992.

8. For traditions of the Quénum family, including reference to its early slaving activities, see Quénum 1981. 

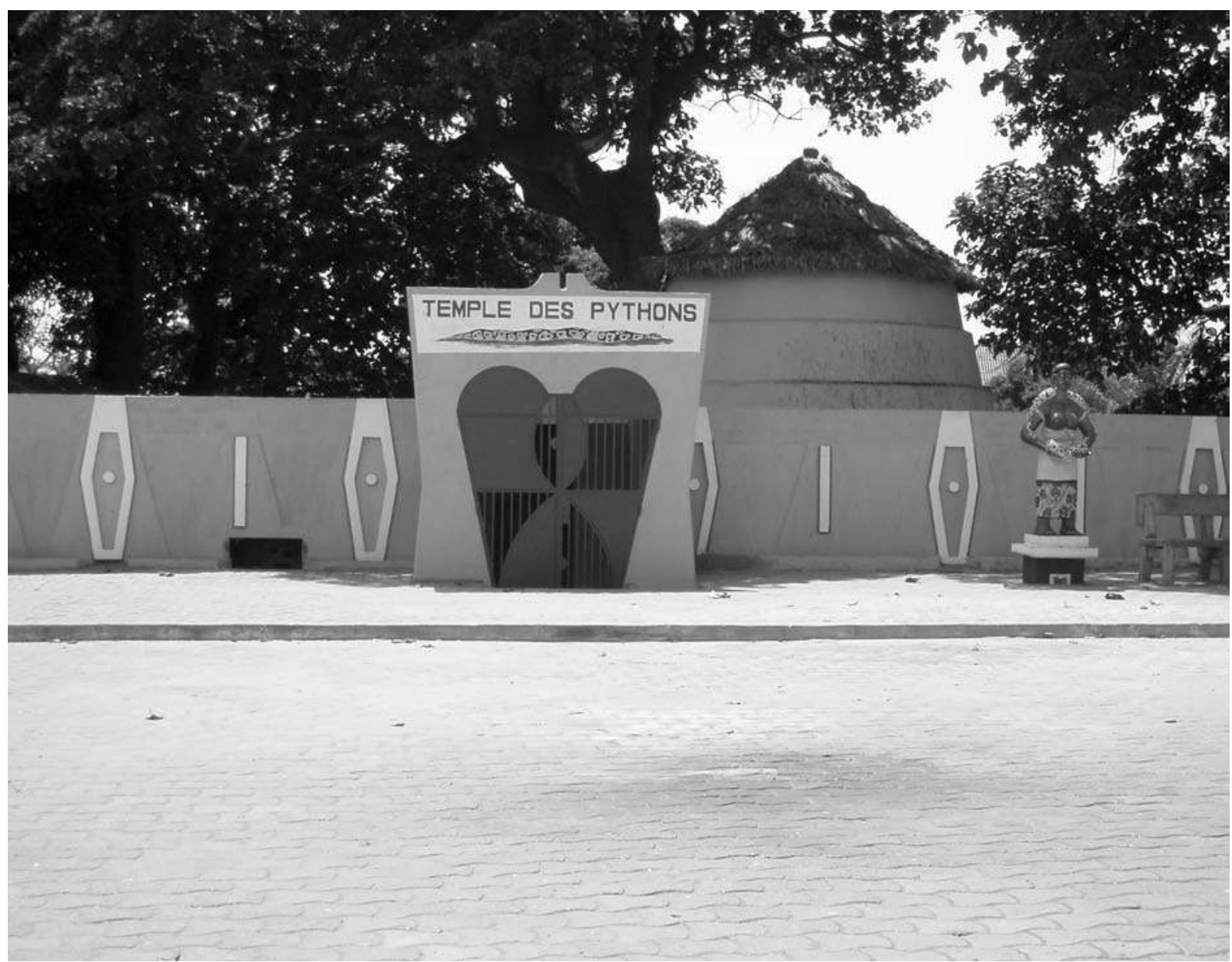

Recollections of this earlier participation in the slave trade have (at least until very recent times) generally been of an unapologetic, or at least non-judgemental, character. The earliest recoverable stratum in Ouidah's collective memory of the slave trade is to be found in the remembered praise-names of nineteenth-century merchants, the ancestors of families still prominent today, some of which do refer explicitly to trading in slaves, without any discernible sense of moral compunction. ${ }^{9}$ By the mid-nineteenth century, however, when the international campaign for the suppression of the slave trade began to impinge upon Ouidah's consciousness, the need for a moral defense of the trade was felt by at least some of those involved in it. Francisco Felix de Souza in the 1840 os justified his participation in the slave trade by reference to the Dahomian practice of human sacrifice, claiming that those sold overseas were thereby saved from being killed, and the same argument was put forward by the Yovogan, or
Dahomian Governor of Ouidah, in negotiations with the British government in $1850 .{ }^{10}$ This rationalization of slave-trading is still sometimes repeated by members of the de Souza family down to the present; as it was, for example, to a understandably sceptical Henry Louis Gates, Jr, in his visit to Ouidah for his recent television programme on the West African "slave kingdoms" (Gates 1999). But in general ancestral participation in the slave trade is simply accepted as a fact, explained (if not justified) by the profits which it yielded, and by the customs of the period.

9. Examples are praise-names of Gnahoui and de Souza, recorded by Agbo 1959: 235-6; for discussion, see Law 2004: 149-50.

10. National Archives, London, C096/4, Lieutenant-Governor Hill, Cape Coast, 11 Nov. 1844; UK Parliamentary Papers: Correspondence relating to the Slave Trade 1850-1, Class A, inclosure 1 in no.198, Journal of Lieutenant Forbes, 18 March 1850. Cf. also reported remarks of King Glèlè of Dahomey in 1864 (Burton 1864: ii, 276). 
For the people of Ouidah in recent times, and more especially for its educated elite, the historical significance of the slave trade has commonly been seen in terms of the town's pre-eminence in international commerce, and hence in the progress of European-derived "civilisation", rather than of the exploitation and sufferings of the slaves. Thus the demolition of the French fort by the colonial authorities in 1908 evoked protests that the building was an important monument of local history, and vain demands for its reconstruction as a museum. The history which the fort commemorated was seen in essentially positive terms, attesting not only to the longevity of the connection with France, but also to the origins of this relationship in a free and equal friendship, rather than in colonial subjection (Agbo 1959: 25-8). ${ }^{11}$ Likewise, the path along which slaves were taken from Ouidah to the sea-shore, rather than a site of the sufferings of the enslaved, was for local historian Casimir Agbo a source of local pride -"la première route internationale de ce pays" (Agbo 1959: 111).

Perceptions of the slave trade in Ouidah have also been affected by awareness that significant numbers of former slaves returned, especially from Bahia in Brazil, to re-settle in West Africa (Turner 1975; Guran 1999). Several families in Ouidah today, especially in the quarter called Maro in the south-west of the town, acknowledge descent from such Brazilian repatriates, arriving from the 1830s onwards (Law 2004: 179-83). The former slaves themselves seem to have maintained a positive perception of their time in Brazil. A British visitor to Ouidah in 1845 was surprised at the apparent enjoyment of ex-slaves from Maro quarter as they watched new slaves being taken to the beach for embarkation: when he queried their attitude, "they declared they had spent their happiest days in Bahia” (Duncan 1847: i, 201). This viewpoint has evidently been fed into the perceptions of the wider community as well. Agbo thus takes a determinedly upbeat view of the slave trade, based on the experience of these repatriated ex-slaves -and on the misconception that they were typical in their experience rather than, as they were in fact, only a tiny minority of those shipped to the Americas. After referring briefly to the brutalities of enslavement and the export trade, he continues:

Cependant, aux dires de certains anciens esclaves, ils étaient assez bien traités par leurs patrons dans les colonies d'Amérique [...] Étant presque tous [sic] libérés après 30 ans de service, ils arrivaient ainsi à goûter de la civilisation. La plupart d'entre eux [sic] revinrent dans leur pays d'origine, les enfants de ceux qui ne vivaient plus vinrent aussi.
Agbo's evocation of the traffic along the route from Ouidah south to the seashore likewise emphasizes its two-way character: "foulé par tant d'esclaves partant pour l'exil ou en revenant après trente ou quarante années de captivité" (Agbo 1959: 52, 111).

\section{Le Musée d'Histoire de Ouidah, 1967}

The project of a historical museum in Ouidah, first mooted in the context of the demolition of the French fort in 1908, was not realized until the 1960s, when it found its location in the former Portuguese fort. The latter had been reoccupied, after a period of abandonment, in 1865, and during the colonial period remained an anomalous Portuguese enclave within the French territory of Dahomey, its evacuation being forced by the independent Republic of Dahomey only in 1961. The fort, and more especially the Roman Catholic chapel inside it, served throughout this time as an important social and religious focus for the Afro-Brazilian community in Ouidah. In consequence of this unusual history, it is also the only one of the three European forts in Ouidah which has survived in a recognisable form.

Following the Portuguese evacuation of 1961, the fort was adopted as the site of the Musée d'Histoire de Ouidah, which was opened in $1967 .{ }^{12}$ The basic organization, and indeed most if not all of the detail, of the museum exhibition as it was constituted in 1967 persists down to the present. ${ }^{13}$ Subsequent restoration of the buildings, financed by the French government in 1982-4 and by the Calouste Gulbenkian Foundation of Portugal in 198890, seems not to have changed the character of the museum exhibition itself. ${ }^{14}$ The exhibition is organized in a series of rooms each devoted to a particular aspect, the sequence being partly geographical and partly chronological. It begins with the European discovery of

11. Agbo himself, it may be noted, belonged to a family which had formerly served the French fort.

12. This was part of a more general imaginative programme of museum development by successive governments of Dahomey/Bénin, following the establishment of the Museum of Abomey, comprising part of the former palace of the Kings of Dahomey (1943), and to be followed by the Honmè Museum, in the palace of the former Kings of Porto-Novo [1987), and the Akaba Idena Museum, a gateway in the city walls of Ketu (1995): see Ministère de la Culture et des Communications 1995.

13. For the original layout of the exhibition, see the first version of the museum guide-book (Verger and da Cruz 1969).

14. In the 1990s the exhibition was expanded to include objects recovered in archaeological excavations at Savi, the pre-1727 capital of the Hweda kingdom, but these have been inserted haphazardly, where space was available, without disturbing the arrangement of the existing exhibition. 


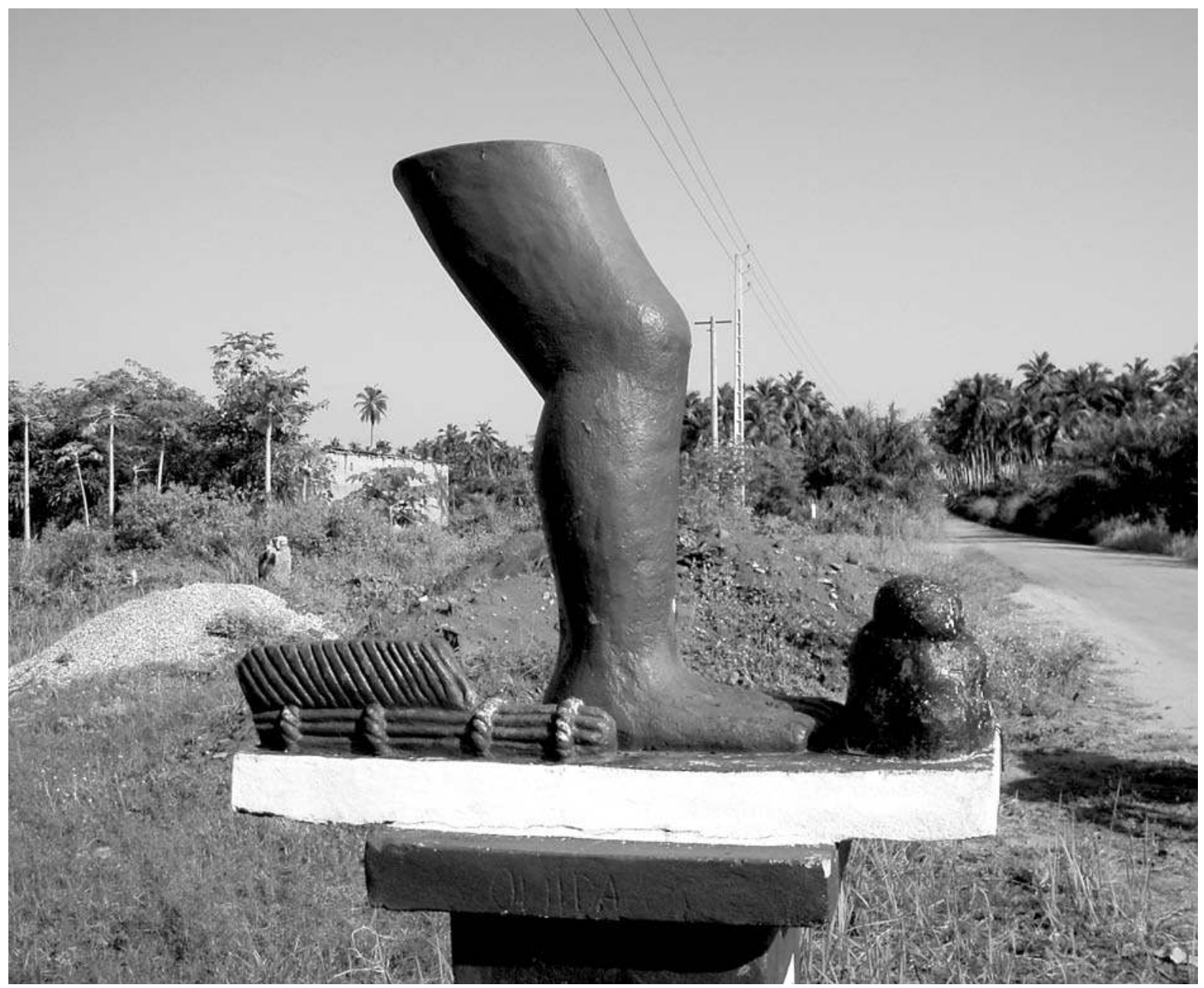

Fig. 6 Sculpture représentant Agoli Agbo (1894-1900), le roi aboméen qui aurait dû «balayer » les envahisseurs du royaume, La Route de l'Esclave, Ouidah, 2005. CEuvre de Cyprien Tokoudagba. Photo G. Ciarcia.

the coast of Bénin, and the European forts established in Ouidah, followed by the two African kingdoms to which these trading posts were successively subject, Hweda (Savi) and Dahomey; and then proceeds through the trans-Atlantic slave trade to slavery in Brazil. The focus then shifts to reciprocal interactions between Bénin and the New World, with treatments of the cultural influence of Bénin on Brazil (and also, more briefly, on Cuba and Haiti), especially in the sphere of religion, and the influence of Brazil on Bénin, through the settlement of Brazilian emigrants there. Finally, the exhibition focuses on the Roman Catholic Church in both Bénin and the New World, with emphasis given to toleration and syncretism between Christianity and African religious traditions.

In this treatment, African agency is highlighted, with concomitant acknowledgement of African complicity in the operation of the slave trade: "Les souverains
d'Afrique noire n'étaient pas les initiateurs de la traite, mais finalement beaucoup s'en étaient enrichis". ${ }^{15}$ The emphasis, however, is less on the sufferings of the slaves than on mutual cultural influences between Africa and the New World. The Middle Passage is central to the exhibition only in a geographical sense, as providing the conduit through which African culture was transmitted to the Americas (and Brazilian culture back to Africa). The reasons for the adoption of this particular perspective seem clear enough. Undoubtedly, this conception owes something to the impact of one particular person, the French scholar (later settled in Brazil) Pierre Verger, who played a central role in the setting up of the exhibition, supplying much of the photographic material and co-writing the original museum guidebook, and whose own published work on the Bénin area

15. Exhibit label in the Musée d'Histoire. 


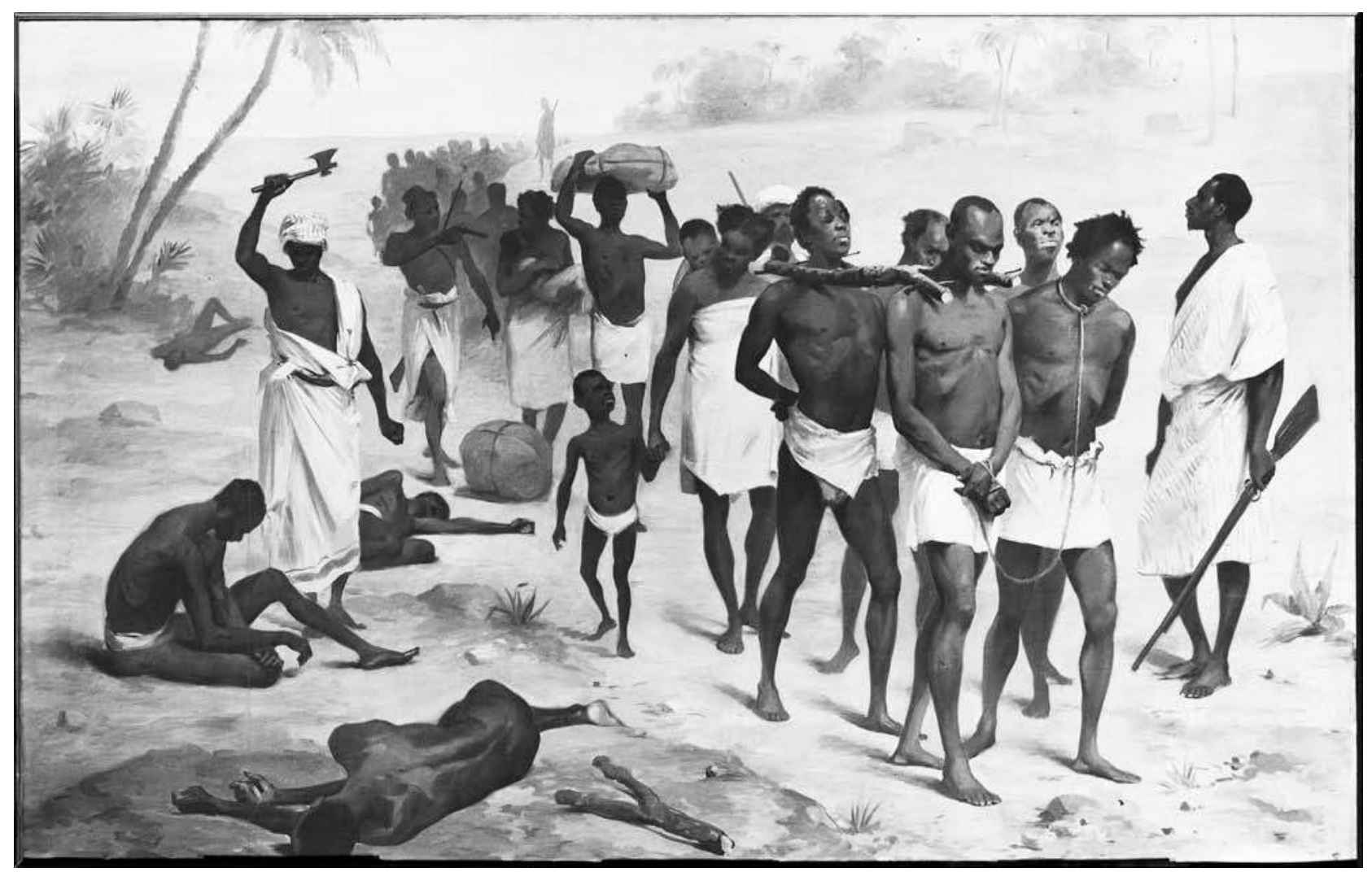

Fig. 7 Anonyme, Convoi d'esclaves en Afrique, avant 1878, musée du quai Branly @ RMN.

consistently emphasized reciprocal cultural links between Africa and Brazil (e.g. Verger et al. 1952; Verger 1957, 1968). But in this, Verger's work clearly reflected (while also reinforcing) local perceptions. Additionally, the museum was explicitly conceived as a museum of the history of Ouidah, rather than of the slave trade; and in effect more particularly as a museum of the AfroBrazilian community in the town. Although in one sense the case of Ouidah is comparable to that of Cape Coast Castle, in that the shape of the exhibition was strongly influenced by the particular interests and perceptions of a locally resident group of African-American origin, in Ouidah this was a much longer-established group, which was much more integrated into the wider local community, and whose historical relationship to the slave trade was more ambivalent, counting ancestors among its beneficiaries as well as its victims. Also, the fact that this group's links were specifically to Brazil rather than, as in the Ghanaian case, to the USA, was critically significant; the emphasis in Ouidah on the reciprocal trans-Atlantic cultural influences arising from the slave trade parallels similar concerns in Brazil itself. ${ }^{16}$
La Route de l'Esclave, 1992-93

A more general project of historical commemoration in Ouidah developed in the 1990s. This movement had both a local and a wider national (and international) background. The local context was the desire of prominent members of families of Ouidah origin to devise means for the economic regeneration of the town. This aspiration was articulated especially by the Union Générale pour le Développement de Ouidah (UGDO), which held its inaugural conference in the town in 1985; although advertised as a conference on "Les voies de la renaissance" of Ouidah, it was in fact largely concerned with its history (“Origines") (UGDO 1985). ${ }^{17}$ The link was partly that this history was, in its most recent phase, one of decline, and analysis of this process of decline was seen as a necessary preliminary to the work of

16. Cf. a Brazilian television programme/video on cultural links with Bénin (Barbieri 1998).

17. UGDO also sponsored the publication of a new version of the guidebook of the Historical Museum (Assogba 1990). 


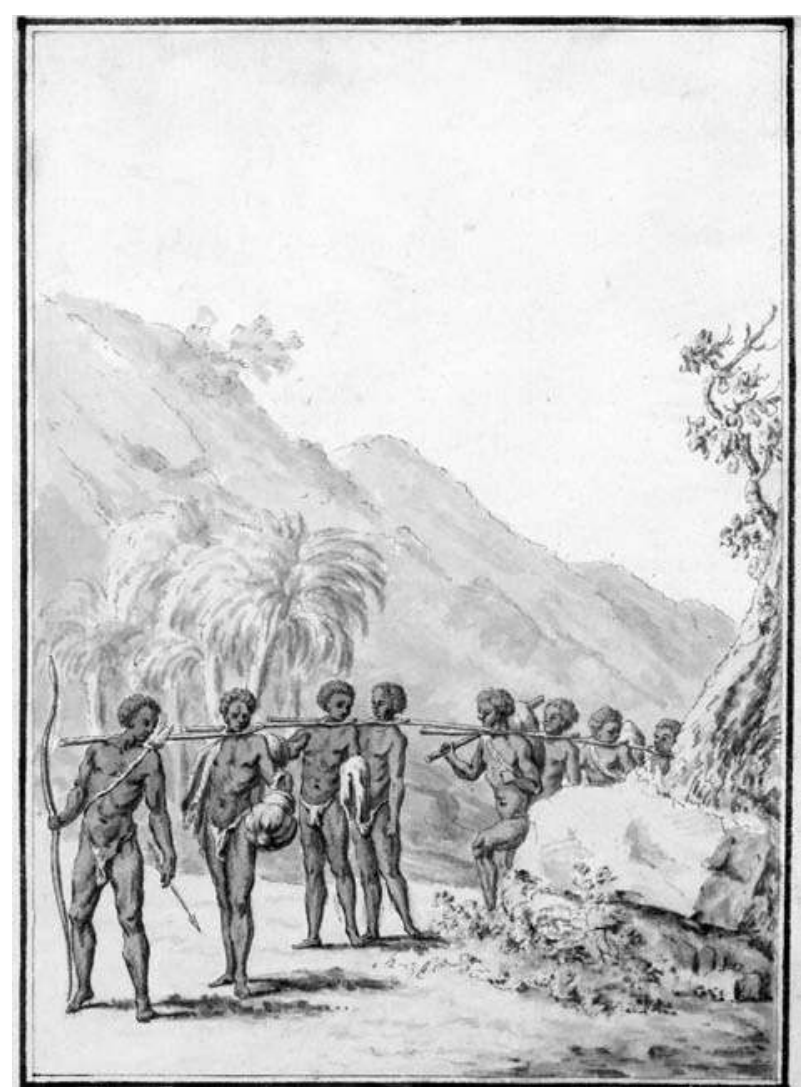

Fig. 8 James Bagire (dessinateur), Manière dont on conduit les nègres esclaves, 1779, musée du quai Branly (c) RMN, photo Jean-Gilles Berizzi.

regeneration; but also that the town's historical heritage was seen as providing a potential basis for this regeneration, through its development as a cultural and tourism centre.

At a national level, this concern was reflected in a survey of the architectural "patrimoine" of Ouidah undertaken in 1990-1, as a joint project of the French overseas development agency (ORSTOM) and the Bénin Ministère de l'Environnement (more specifically, its Service d'Études Régionales d'Habitat et d'Aménagement Urbain) (Sinou and Agbo 1991). ${ }^{18}$ This reinforced interest in the development of "heritage" tourism, by identifying potentially usable sites. In particular, this included the first explicit discussion of La Route de l'Esclave, the road from Ouidah to the beach along which slaves were marched in order to be embarked on slave ships, as well as of the European forts etc. in Ouidah town itself.

These local initiatives were seconded by external agencies, specifically by UN-sponsored developments, linked to the UNESCO project also called "La Route de l'Esclave". The idea of this project was initiated in Haiti in 1991, as a counterpoint to the celebration of the quincentenary of Columbus's landfall in the Americas in 1492, which in general appeared to conceive of transAtlantic linkages exclusively in terms of Europe and America, to the neglect of the role of Africa and more especially of the trade in African slaves. Two major international conferences sponsored by UNESCO were held at Ouidah-representing, of course, an enormous, albeit temporary, stimulus to the town's ailing economy. The first, originally planned for 1992 though not actually held until February 1993 (but nevertheless still called officially "Ouidah 92") was a Festival des arts et cultures vodun, devoted to African and African-American religions and their cultural and artistic expressions, and thus maintained the emphasis on reciprocal cultural influences between Africa and America. A religious ceremony at the beach at Ouidah which was revived in connection with the conference, since performed annually, likewise celebrated Ouidah's role in the transmission of the vodun religious tradition to the Americas (Sutherland 1999); this perspective was also stressed in official Bénin tourism policy of this period, with its slogan "Le Bénin, berceau du vodoun". The second conference, held in September 1994, officially launched the project of "La Route de l'esclave", under the title "De la traite négrière au défi du développement : réflexions sur les conditions de la paix mondiale". This had a wider set of concerns, including the implications of the slave trade for international and racial inequalities and African economic development, though here too around a quarter of the papers presented deal in one way or another with cultural continuities across the Atlantic (Diène 1998). Despite this shift of emphasis towards the negative impact of the slave trade on Africa, as well as on African-Americans, it may be noted that there was still no disposition to deny African agency/complicity in slaving. President Soglo of Bénin, in his speech opening the conference, explicitly invoked African responsibility, linking the history of the slave trade to the contemporary problems of Africa:

Il ne servirait à rien non plus de dissimuler nos propres responsabilités dans les désastres qui se sont abattus ou continuent de s'abattre sur nous. Nos complicités dans la traite sont bien établies, nos divisions absurdes, nos errements collectifs, l'esclavage comme institution endogène [...] les fautes de gestion de gouvernement, voire le comportement prédateur de certains dirigeants [...] (Diène 1998: 7).

18. See also the coffee-table spin-off by one of the authors (Sinou 1995). 
The objectives of the Slave Route project included not only the promotion of research and popular education on the slave trade, but also "le tourisme culturel", focused on monuments and sites linked to the trade, which was seen as having an economically regenerative as well as an educational function; the Bénin government was especially interested in this aspect. ${ }^{19}$ In the case of Ouidah, however, an obvious problem was that the major existing monuments, such as the Portuguese fort and the de Souza family compound, relate to the slave-traders rather than to the victims of the trade. Moreover, the surviving buildings of the Ouidah fort, unlike those in Ghana, include no recognisable "slave dungeons", basically because it was built in mud rather than stone or brick, and hence subject to periodic reconstruction. ${ }^{20}$

For commemoration of the experience of the slaves themselves, attention was focused, as anticipated in the 1991 report on the town's architectural "patrimoine", on La Route de l'Esclave from Ouidah to the point of embarkation on the beach. In the context of the Ouidah ' 92 conference, work was begun on the development of cultural-touristic sites along $\mathrm{La}$

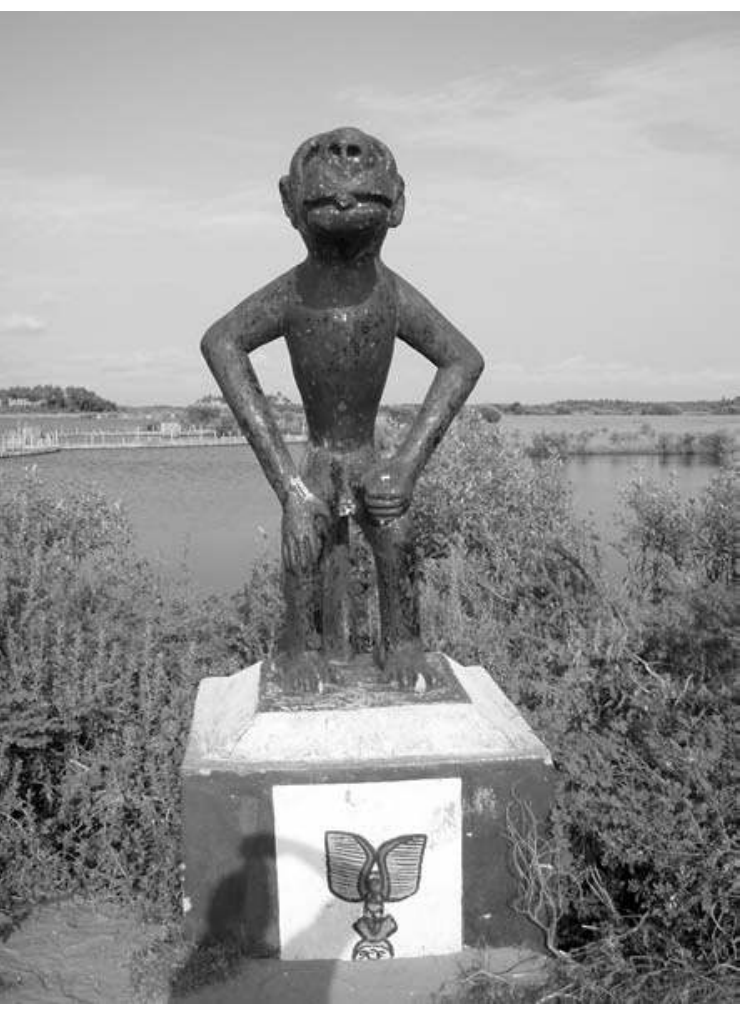

Fig. 9 Statue du singe, représentation du roi aboméen Adandozan (1797-1818), La Route de l'Esclave, Ouidah, 2005. Euvre de Cyprien Tokoudagba. Photo G. Ciarcia. bien évidemment n'appelait pas d'importants investissements matériels", so that "un projet de mémorisation impliquerait d'inventer des formes nouvelles de marquage de l'espace" (Sinou 1995: 173).

In fact, work on La Route de l'Esclave consisted for the most part in the construction of new "monuments" rather than the identification of existing ones, in particular the placing of statues at intervals along the whole length of the route. These statues, representing Dahomian gods, kings and warriors, relate to the history and culture of the region in general, rather than directly to the slave trade, and might indeed be thought to commemorate, in effect, the slave-traders rather than the victims of the trade. The slaves themselves were, however, explicitly commemorated in a monument at the village of Zoungbodji, halfway to the beach: this was conceived as a memorial specifically for those who died in transit to the coast, since its location is said to have been a burial place for slaves who died while awaiting embarkation. Subsequently, however, this was complemented by a monument to the slaves actually exported, at the point of embarkation on the beach, Route de l'Esclave, with the construction or identification of monuments along the road. ${ }^{21}$ This enterprise posed a considerable practical difficulty, in that there are few if any material remains which can be connected with this process, although more than a million slaves undoubtedly trod this path on their way into transAtlantic slavery (or death in the Middle Passage). As the authors of the 1991 report had observed, there are no "édifices remarquables" along La Route de l'Esclave, the trade not requiring the building of permanent premises -the only substantial monument along the route, the French colonial customs post at the beach, dating in fact from after the period of the slave trade (Sinou and Agbo 1991: 117). As one of them later reflected, "Il est en effet difficile d'évoquer une activité de transit [...] qui completed in 1996. This structure was called La Porte $d u$ Non-Retour, in transparent imitation of the famous Porte du Non-Retour in the Slave House on Gorée Island (now also imitated in Cape Coast Castle). But whereas the Gorée and Cape Coast structures are real doors, through which slaves were actually taken from their places of confinement to be embarked on ships, the

19. See the paper presented at the 1994 conference by an official of the Bénin Ministère du Commerce et du Tourisme (Lokossou 1998).

20. As noted by Singleton 1999: 159-60. The present layout of the buildings seems to reflect their reconstruction at the time of the Portuguese reoccupation of the fort in 1865 .

21. Described e.g. in a booklet produced for the 1994 conference (Soumonni, Codo and Adandé 1994: 128-9); and in two recent tourism guide-books (de Souza and Evejah 1998; de Souza 2000). 
Ouidah variant is purely symbolic, marking a space which was previously empty.

Attempts were also made to identify actual historical sites connected with the operation of the slave trade, but some of these raise problems of authenticity analogous to those surrounding the Maison des Esclaves at Gorée. For example, the starting point of La Route de l'Esclave is a supposed Place aux encheres of slaves, marked by a tree immediately south of the de Souza family compound. This was undoubtedly the site of a pre-colonial market, which is described, for example (under the name "Adjido Market"), by the British Consul Richard Burton in 1863 (Burton 1864: $1,49,107$ ). It is doubtful, however, whether slaves were ever sold in this market, or indeed at any other public market-place in Ouidah, since the contemporary evidence clearly indicates that slaves were purchased in Ouidah out of merchants' houses, rather than at any central place (Law 2004: 132). ${ }^{22}$

Similar doubts arise with regard to a second site in Zoungbodji, which is nowadays identified as that of a "barracoon", or building where slaves were lodged, on their way to the beach (and adjacent to the supposed burial site on which the modern monument mentioned earlier was erected). The place is called Zomaï literally "Fire prohibited", which is also the name of a quarter on the west of Ouidah town itself, which was originally a combined warehouse and country retreat established by Francisco Felix de Souza. The name Zomaï is nowadays explained as alluding to the fact that slaves were brought to the barracoons by night and kept there in darkness, as a means of control. This seems doubtful, however, since earlier explanations of the name (as given, for example, to Consul Burton in 1863) link it more plausibly to the use of these buildings as storehouses for gunpowder (Burton 1864: i, 107).

It is, perhaps, uncharitable to dismiss such cases as mere invention. Rather, they represent a form of imaginative reconstruction. The people of Ouidah, it may be suggested, being aware in general terms of the importance of the slave trade in the history of their town, have a tendency to link objects and sites to the slave trade, by a process of (mis)informed speculation. ${ }^{23}$ Existing traditions of a former market at Adjido and a warehouse

22. It should also be noted that slaves destined for export in Ouidah were not, in fact, auctioned, but sold at fixed prices set by the local political authorities (Law 2004: 129-31).

23. This was illustrated to the author on a visit to Ouidah in June 1997, when I was shown a metal object which had been found in the town and brought into the Musée d'Histoire, which was assumed to be a form of shackle for slaves, but which, in fact, was recognisably a horse-bit.

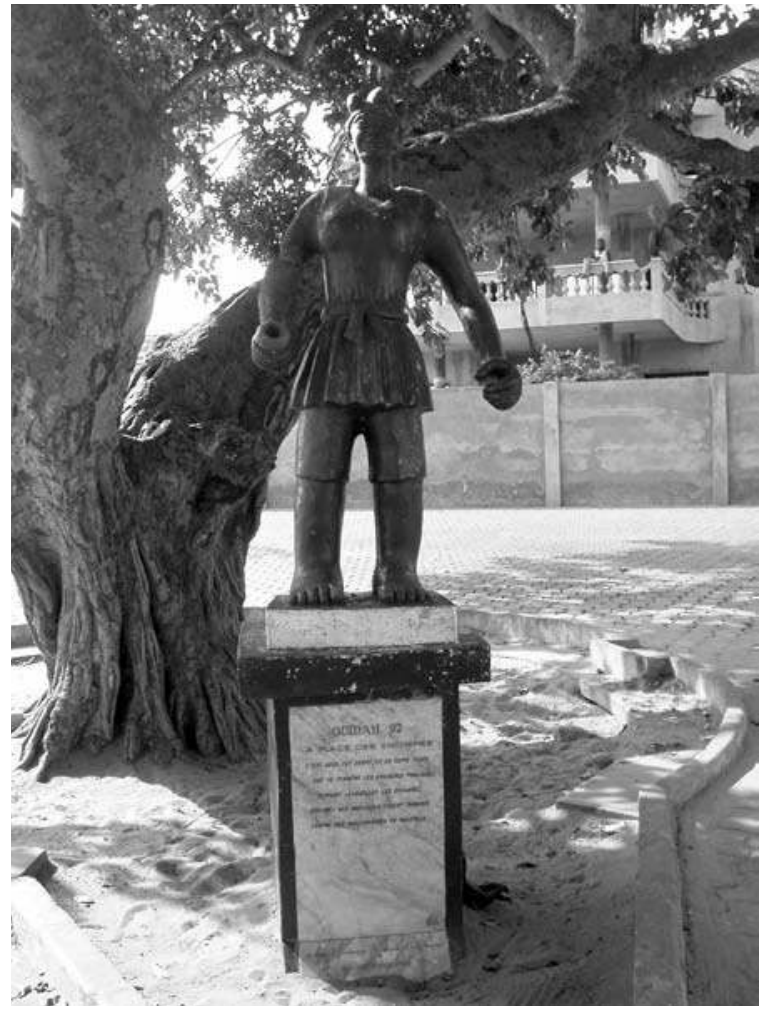

Fig. 10 Site dit de "La place des enchères ", devant la maison des descendants de Francisco Felix de Souza, La Route de l'Esclave, Ouidah, 2005. Fuvre de Cyprien Tokoudagba. Photo G. Ciarcia.

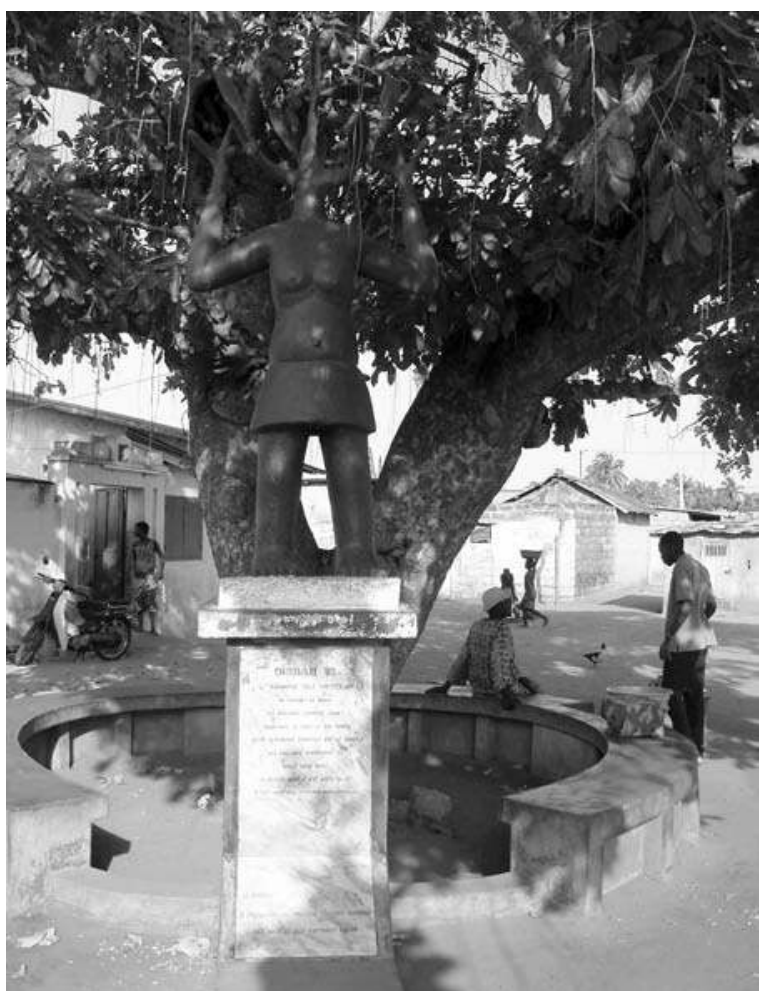

Fig. 11 Site dit de "L'arbre du Retour ", La Route de l'Esclave, village de Zoungobodji, 2005. Fuvre de Cyprien Tokoudagba. Photo G. Ciarcia. 
at Zomaï were therefore understandably, even if mistakenly, interpreted with reference to the sale and storage of slaves.

\section{L'Arbre de I'Oubli and L'Arbre du Retour}

More difficult and more interesting questions arise with regard to two other supposedly historical sites identified along La Route de l'Esclave. These are two trees: one (which no longer exists, but whose site is still remembered), just south of Ouidah, and another (still extant) in the central square of the village of Zoungbodji, called respectively L'Arbre de l'Oubli and L'Arbre du Retour. It is claimed that slaves on their way to embarkation for export were made to walk round L'Arbre de l'Oubli (women seven times, men nine times) to make them lose their memories, in order to prevent their spirits returning to trouble those who had enslaved and sold them; and they also went round L'Arbre du Retour (three times) in order to ensure that they would come back to Africa, this intended re-crossing of the Atlantic also being explained as spiritual, rather than physical. Logic would suggest that the slaves' attempt to secure their return was in defiance of the slave merchants who sold them, but it is said to have been permitted by the latter, in order to give the enslaved hope for the future.

This account thus incorporates seemingly contradictory narratives of an attempt on the part of the slavetraders, on the one hand, to obliterate the cultural identity of their victims; and on the other hand, the resistance of the slaves themselves to this process of deracination. The struggle is set within the framework of indigenous African agency in the slave trade, concerning relations between the slaves and their African sellers rather than their European and American purchasers. The suggestion of concern to ward off the posthumous vengeance of the enslaved is intuitively plausible, since it is consistent with contemporary documentation of how the export trade in slaves was conceptualized by the Africans involved in it. Many accounts from the period of the slave trade report the common belief of African-born slaves in the Americas that when they died, their souls would return to Africa, which indeed caused some of them to commit suicide as a means of returning home. ${ }^{24}$ The ritual at L'Arbre de l'Oubli may be interpreted, as suggested by a Béninois commentator, as a policy on the part of the Kings of Dahomey "pour assurer le contrôle psycho-religieux de la traite des esclaves", "une manière d'exorciser le cas de conscience que représentaient les départs sans retour des femmes et des hommes arrachés à la terre de leurs ancêtres" (Soglo 1995: 101, with n.1).

Despite this apparent prima facie plausibility, however, there are grounds for doubt about these stories. First, the suggestion that slave-dealers would have taken the substantial time out required for all slaves to run round trees at two separate points on the journey to the beach is inherently difficult to credit. Further, the stories themselves are not well documented. That of the slaves' circumambulation of the more northerly tree, to the best of my knowledge, was first recorded in print only in 1990 (first in Assogba 1990: 30); while the actual name L'Arbre de l'Oubli has not been traced prior to the official constitution of the touristic Route de l'Esclave in 1992-93, this tree being known earlier as L'Arbre des Capitaines. The circumambulation of the more southerly tree, together with the name L'Arbre de l'Oubli, seems likewise to be undocumented before 199293. Even today, there is evidently some uncertainty in local tradition about the historical significance of the two trees, and indeed a degree of confusion between them. Both are sometimes called "Agajatin", "Agaja's Tree", referring to the King of Dahomey who conquered Ouidah in 1727; and the survey of Ouidah's architectural "patrimoine" in 1991 reports, without comment, contradictory stories that both mark the place where Agaja first drank European gin, following the conquest (Sinou and Agbo 1991: 115-6, 161). ${ }^{25}$

This is not to say that the trees are not, in some sense, genuine monuments dating from the period of the slave trade. The more northerly of them, under its alternative name of L'Arbre des Capitaines, is in fact explicitly documented in a number of contemporary accounts from the late eighteenth century onwards, as the place where European traders (and other European visitors) were formally welcomed by the Yovogan and other local authorities of Ouidah (e.g. Dalzel 1793: 227; Pires 1957: 29); some of these do describe a ceremony of circumambulation, but it is the Ouidah chiefs, rather than slaves destined for export, who are said to have processed around the tree (three times), prior to greeting the Europeans. ${ }^{26}$ None of these early sources, however,

24. For an account of this belief relating specifically to slaves embarked from Ouidah, see Phillips 1732: 219.

25. This gives the name "Agajatin" to the tree at Zoungbodji; whereas the later account by Sinou (1995: 89) applies it to the "Captain's Tree".

26. The circling of the tree is described in Archives Nationales, Section d'Outre-Mer, Aix-en-Provence, Archives des Colonies C6/27, Gourg, "Mémoire pour servir d'instruction au Directeur qui me succédera au comptoir de Juda", 1791; National Archives, London, F084/886, Journal of Vice-Consul Louis Fraser, 23 July 1851; Burton 1864: i, 39-45. 



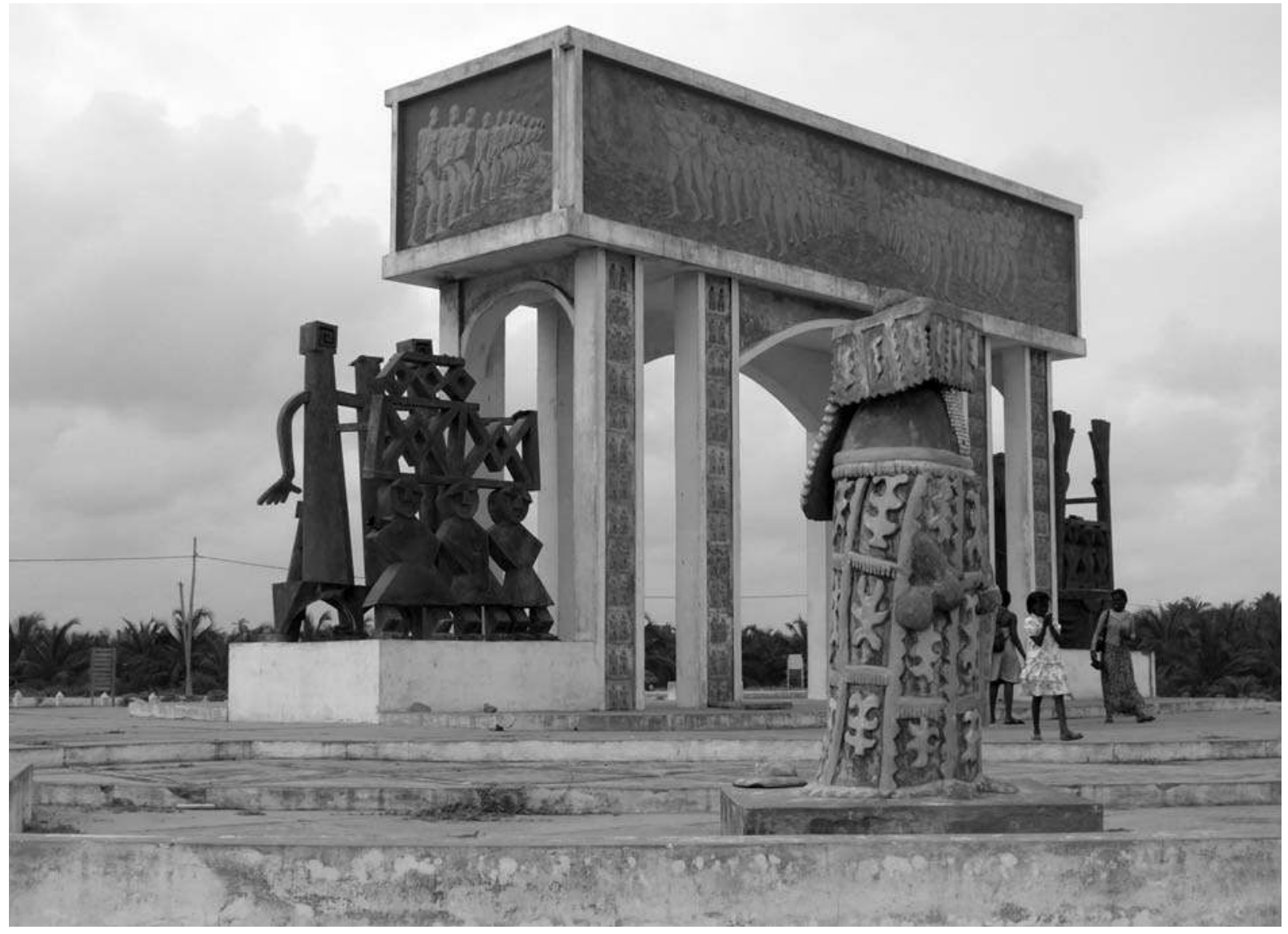

Fig. 13 Parvis de la «Porte du Non-Retour », plage de Ouidah, 2007.

Fuvres de Fortuné Bandeira, Dominique Gnonnou « Kouas » et Yves Kpède. Photo J. Noret.

PAGE PRÉCÉDENTE Fig. 12 Statue commémorant la détention des esclaves dans la " case de Zomaï ", La Route de l'Esclave, 1995. Photo M. Guran.

alludes to any circling of the tree by slaves. As regards the tree at Zoungbodji, likewise, although the evidence is more ambiguous, there are early references to a prominent tree (or trees) there, which is probably the same as that nowadays identified as the L'Arbre du Retour: Portuguese missionaries in 1797 were welcomed by the chief of Zoungbodji under "two leafy trees" in an open space in the village (Pires 1957: 28), while an account of 1865 refers to a "palaver tree" where the local authorities heard judicial cases (da Silva 1866: 24-5). But, here again, no early source links the tree to the idea of the "return" of transported slaves. Even in the 1990s, indeed, other explanations of the historical significance of the tree remained current: in addition to its linking to King Agaja's celebratory drink of gin following his conquest of Ouidah, noted above, an alternative story told locally asserts that the tree commemorates the suppression of an early rebellion against Dahomian rule, marking the grave of four rebels executed by Agaja on the occasion of the Dahomian reconquest. ${ }^{27}$
The real problem about the stories of L'Arbre de l'Oubli and L'Arbre du Retour, however, is not so much the lack of contemporary corroboration in the pre-colonial period, as the lack of fit with earlier thinking about the slave trade as reflected for example in Agbo's history cited earlier, which contains no hint that the slave-dealers of Ouidah (or Dahomians more generally) felt any problems of conscience with regard to the trade. Also, the insistence on the purely spiritual nature of the return which the slavers sought to prevent and the slaves to ensure -in common with the concept of the Porte du Non-Retour subsequently constructed on Ouidah beachsits oddly with the well-known fact, emphasized in earlier accounts, that some slaves did in fact physically return to Ouidah. What we seem to be dealing with here is a combination (or juxtaposition) of two divergent perceptions of the significance of the slave trade: the local Ouidah perception of it as involving two-way move-

27. Told to the author at Zoungbodji on a visit in June 199 ? 
ment and cultural influences, and an externally derived perception stressing one-way deportation and cultural deracination.

Although this combination may have been in its origins adventitious, and despite its logical untidiness, it may be suggested that the end result can be read as an empirically rounded and intellectually subtle representation of the slave trade; and in this context detailed historical accuracy is perhaps of secondary importance. A modern commentator has puzzled over the flagrant contradiction between the stories told of the two trees: "Si à l'arbre de l'oubli, l'esclave devait perdre la mémoire de son passé, de sa culture, comment pouvait-on s'assurer que son âme reviendrait sur la terre des ancêtres après la mort?" (Soglo 1995: 101, n.1). But this, surely, is to adopt too literal an approach. More charitably (or more creatively), the two counterposed tree stories express a real contradiction in the operation of the slave trade, and to that extent can be read as complementary rather than contradictory. This contradiction is, in fact, embedded throughout the commemorative project of La Route de l'Esclave, whose general emphasis on cultural deracination stands in ironic contrast to the transAtlantic cultural continuities which were the theme of the Ouidah ' 92 conference which gave rise to it. ${ }^{28}$ The monuments at Zoungbodji and the beach evoke slaves' loss of identity, but also feature prominently the iconographic motif of an African masquerade (specifically, the Yoruba gelede mask, originally adopted as the logo of the Ouidah 92 conference), which is explicitly understood and explained as alluding to the resilience of African culture, and its survival in the slave and postslavery societies of the Americas. Viewed from this perspective, it may be said that the perceived contradiction between L'Arbre de l'Oubli and L'Arbre du Retour is the contradiction of the slave-trading system itself: the logic of the system was to obliterate slaves' cultural identities, but the historical reality is that slaves and their descendants have resisted this sort of deracination, to considerable effect.

\section{From commemoration to "repentance", 1998}

In conclusion, it may be noted that the shift of emphasis towards commemoration of the victims of the slave trade which marked the commemorative project at Ouidah in the 1990 s was in evident contradiction with the community's earlier essentially positive recollec- tion of its historical role in the trade. This tension was explicitly acknowledged in the institution, in 1998, of an annual Cérémonie du repentir (Comité d'organisation de la journée du Repentir 1998). ${ }^{29}$ This event involves a procession from Ouidah to Zoungbdoji, to yet another newly constructed monument, which was conceived as a counterpoint to the slave barracoon of Zomaï, and called in contrast Zomachi or "Eternal Light" (lit. "The light will not go out"). In speeches at the monument, pardon is asked from the descendants of transported slaves for Ouidah's participation in their enslavement and deportation. Although part of the stimulus for this venture seems to have come from a group of AfricanAmericans (Rastafarians from Martinique) who had settled in Bénin in 1997, and whose leader was one of the speakers at the inaugural ceremony, the main initiative clearly originated from within the Ouidah community itself, the principal organizer being a locally based retired academic, Honorat Aguessy. ${ }^{30}$ This represents a significant change from earlier perceptions of the slave trade, but there are also important elements of continuity. In particular, in this continuing dialogue of Ouidah with its past, it is noteworthy that the emphasis remains on African agency, and on the relations of Africa with its Diaspora.

mots clés / keywords : slave-trade // traite négrière • memory // mémoire • commemoration // commémoration • Diaspora // Diaspora.

\author{
Department of History \\ University of Stirling, Scotland \\ r.c.c.law@stir.ac.uk
}

28. As also emphasized by Rush 2001.

29. It should be noted that the reference by Sutherland (1999: 196, 207) to the lack of any such "ritual of atonement" at Ouidah is based on observations only to 199 ?

30. The ceremony is held on the $3^{\text {rd }}$ Sunday in January. Aguessy now heads the Institut du Développement et des Échanges Endogènes at Ouidah. 


\section{Bibliographie}

\section{Agbo, Casimir}

1959 Histoire de Ouidah du XVI au XXe siècle. Avignon, Presse de la Maison Aubanel Père.

AssogbA, Romain-Philippe Ekanyé 1990 Le Musée d'Histoire de Ouidah :

Découverte de la côte des Esclaves. Cotonou, Éditions Saint-Michel.

\section{BARBIERI, Renato}

1998 Na Rota dos Orixás, Video. Brasilia, Instituto Itaó Cultural.

\section{BURTON, Richard}

1864 A Mission to Gelele, King of Dahomey.

2 vols. London, Tinsley Bros.

CAFURI, Roberta

2000 "Silenzi della memoria: la tratta degli schiavi", Africa: Rivista trimensale di studi e documentazione dell'Istituto Italo-Africano, Roma 55(2): 244-60.

Comité d'organisation de la journée du Repentir

1998 Zomací : marche et cérémonie du repentir, Ouidah, le 18 janvier 1998. Cotonou, Imprimerie Moderne La Solidarité.

\section{Dalzel, Archibald}

1793 The History of Dahomey. London, The Author (repr. London, Frank Cass, 1967).

\section{DA Silva, Carlos Eugenio Corrêa}

1866 Uma Viagem ao Estabelecimento Portuguez S. João de Ajudá na Costa da Mina em 1865. Lisbon, Imprensa Nacional.

De SouzA, Martine and EvejaH, Mère Jah

1998 Bienvenue à Ouidah au Bénin Cotonou, Organisation de la Solidarité Internationale Nouvelle Création.

\section{De Souza, Martine}

2000 Regard sur Ouidah: A Bit of History. Ouidah [The Author].

\section{DE SOUZA, Simone}

1992 La Famille de Souza du Bénin-Togo. Cotonou, Éditions du Bénin.

\section{Diène, Doudou (ed.)}

1998 La Chaîne et le lien : une vision de la traite négrière. Paris, Éditions UNESCO.

DunCAN, John

1847 Travels in Western Africa in 1845 and 1846, 2 vols. London, Richard Bentley (repr. London, Frank Cass, 1968).
ELtis, David and RichARDSON, David 1997 "West Africa and the Transatlantic Slave Trade: new evidence of long-term trends", Slavery and Abolition 18(1): 16-35.

Eltis, David, Lovejoy, Paul E. and RICHARDSON, David

1999 "Slave-trading ports: towards an Atlantic-wide perspective", in Robin Law and Silke Strickrodt (eds), Ports of the Slave Trade [Bights of Benin and Biafra]. Centre of Commonwealth Studies, University of Stirling: 12-34.

GATES, Henry Louis, Jr 1999 "The Slave Kingdoms", episode in the television series "Into Africa with Henry Louis Gates, Jr". London, BBC2.

Guran, Milton

1999 Agudas: os "brasileiros" do Benim. Rio de Janeiro, Editora Nova Fronteira y Editora Gama Filho.

\section{KREAMER, Christine Mullen}

1997 "Contested terrain: cultural negotiation and Ghana's Cape Coast Castle exhibition, Crossroads of People, Crossroads of Trade", paper presented at the conference on "The Atlantic Slave Trade in African and African-American memory", University of Chicago.

\section{LAW, Robin}

2004 Ouidah: The social history of a West African slaving "port", 1727-1892. 0xford, James Currey.

\section{LoKossou, Clément Koudessa}

1998 "Traite négrière et tourisme culturel", in Doudou Diène (ed.), La Chaîne et le Lien : une vision de la traite négrière. Paris, Éditions UNESCO: 561-8.

\section{Ministère de la Culture ET DES COMMUNICATIONS}

1995 Regards sur les musées et monuments du Bénin. Porto-Novo, Ministère de la Culture et des Communications.

\section{Osei-Tutu, Brempong}

2002 "The African American Factor in the commodification of Ghana's Slave Castles", Transactions of the Historical Society of Ghana, new series 6: 115-33.

\section{PHILliPs, Thomas}

1732 "A Journal of a Voyage made in the Hannibal of London, Ann. 1693, 1694", in
Collection of Voyages and Travels. London, Awnsham Churchill and John Churchill: vi, 173-239.

\section{PIREs, Vicente Ferreira}

1957 Viagem de Africa em o reino de Dahomé, ed. Clado Ribeiro de Lessa. São Paulo, Companhia Editoral Nacional.

QUUÉNUM, Maximilien

1981 Les Ancêtres de la famille Quénum.

Langres, Dominique Guéniot.

Rush, Dana

2001 "Contemporary vodun arts of Ouidah, Benin", African Arts 34(4): 32-4?.

SAMB, Djibril (ed.)

1997 Gorée et l'esclavage. Actes du séminaire sur Gorée dans la traite : mythes et réalités [Gorée, $7-8$ avril 1997). Dakar, Institut Fondamental d'Afrique Noire.

\section{Singleton, Thereza A.}

1999 "The Slave Trade remembered on the former Gold and Slave Coasts", Slavery and Abolition 20/1: 150-69.

Sinou, Alain

1995 Le Comptoir de Ouidah : une ville africaine singulière. Paris, Éditions Karthala.

Sinou, Alain and AGBo, Bernardin 1991 Ouidah et son patrimoine. Paris and Cotonou, ORSTOM/SERHAU.

Soglo, Giles Raoul

1995 "Les Xweda : de la formation du royaume de Sayi (Saxe) à la dispersion, XVI'-XVIII siècle". Mémoire de Maîtrise, Université Nationale du Bénin.

Soumonni, Elisée, Codo, Bellarmin C. and ADANDÉ, Joseph (eds)

1994 Le Bénin et la route de l'Esclave. Cotonou, Comité National pour le Bénin du projet "La Route de l'Esclave".

\section{SutherLAND, Peter}

1999 "In memory of the slaves: an African view of the Diaspora in the Americas", in Jean Muteba Rahier (ed.), Representations of Blackness and the Performance of Identities. Westport CT, Bergin and Garvey: 195-211.

TURNER, Jerry Michael

1975 "Les Brésiliens: The Impact of Former Brazilian Slaves upon Dahomey". PhD thesis, Boston University. 
UNION GÉNÉRALE POUR

LE DÉVELOPPEMENT DE OUIDAH

1985 Almanach de Ouidah, Actes du précolloque ORIGINES tenu à Ouidah du 23 au 27 septembre 1985 : Les Voies de la renaissance de Ouidah. Caen, Éditions Kanta.

Verger, Pierre et al.

1952 Les Afro-Américains. Dakar, Institut français d'Afrique noire.

\section{Verger, Pierre}

1957 Dieux d'Afrique : Notes sur le culte des orisa et vodun à Bahia, la Baie de Tous les Saints au Brésil, et à l'ancienne côte des Esclaves. Dakar, Institut Français d'Afrique Noire.

1968 Flux et reflux de la traite des nègres entre le golfe de Bénin et Bahia de Todos os Santos du XVII au XIXe. Paris, Mouton.
Verger, Pierre and Da CRuz, Clément 1969 Musée historique de Ouidah. Porto-Novo, Ministère de l'Éducation et de la Culture/Institut de Recherches Appliquées du Dahomey.

\section{Résumé / Abstract}

Robin Law, Commemoration of the Atlantic Slave Trade in Ouidah. - This paper considers local memory and commemoration of the trans-Atlantic slave trade in Ouidah. It is shown that originally the slave trade was remembered in Ouidah essentially positively, as a source of material benefits, and there was open acknowledgement of the role of local agency in the operation of the trade. The Musée d'Histoire established in 1967 shifted the emphasis to the cultural interactions with the Americas (especially Brazil) which resulted from the slave trade, but still maintained an essentially celebratory attitude. The 'Slave Route' project initiated in 1992/3, however, again shifted the focus to the sufferings of the enslaved victims, and hence to a more negative view of the trade. There remained elements of continuity, however, in the continued acknowledgement of African agency and interest in Africa's relationship with its American Diaspora.
Robin Law, Commémoration de la Traite Atlantique à Ouidah. - Ce texte porte sur la mémoire locale et la commémoration de la traite transatlantique à Ouidah. À l'origine, le commerce d'esclaves à Ouidah était associé à une mémoire positive, appréhendé comme source de profits matériels, et le rôle des autochtones dans l'organisation de ce commerce était clairement reconnu. Le Musée d'Histoire créé en 1967 mit l'accent sur les échanges culturels avec les Amériques (en particulier le Brésil) occasionnés par la traite, tout en continuant à la célébrer. Mais avec le projet de la «Route de l'Esclave »lancé en 1992/3, l'attention s'est recentrée sur les souffrances des victimes de l'esclavage, et donc sur une vision plus négative de la traite. On continue cependant à reconnaître la place de l'Afrique et de son intérêt pour les relations entre l'Afrique et sa diaspora américaine. 